\title{
Levels of Milk Urea, Plasma Constituents and Rumen Liquid Ammonia in Relation to the Feeding of Dairy Cows During Early Lactation
}

\author{
By E. Ropstad, L Vlk-Mo and A O.Refsdal
}

Department of Reproductive Physiology and Pathology, Norwegian College of

Veterınary Medicine, Oslo, Department of Animal Science, Agnicultural University of Norway, Ås, and Norwegian Red Cattle Association, Hamar.

\begin{abstract}
Ropstad, E., L. Vik-Mo and A. O. Refsdal: Levels of milk urea, plasma constituents and rumen liquid ammonia in relation to the feeding of dairy cows during early lactation. Acta vet. scand. 1989, 30, 199-208. - The study was undertaken to establish the relationships between milk and plasma urea levels and protein supply, using traditional and new measures of feed protein value.

Samples of milk and plasma were taken before morning feeding twice weekly for the first 3 months post partum from 21 multiparous cows and 7 heifers. Samples of rumen fluid were collected every second week. The cows were distributed into 4 different feeding groups. Feeding regimens were factorial with respect to protein content of the concentrates (i.e. Low protein (Lp): $12.5 \%$ digestible crude protein (DCP) vs. High protein (Hp): $17.5 \%$ DCP) and concentrate allowances (i.e. Low energy (Le): substandard vs. High energy (He): standard). Silage was offered ad libitum.

The within-anımal coefficients of correlation between milk and plasma urea levels, and between milk urea levels and the levels of ammonia in the rumen fluid were $r=0.88(p<0.001)$ and $r=0.75(p<0.001)$, respectively. Analysis of variance showed the following sources of urea variation to be significant: Protein balance in the rumen (PBV), intake of DCP, intake of amıno acids absorbed in the intestine (AAT), intake of fattening feed units, and the individual animal factor. A similar tendency was found for the variation of ammonia in rumen fluid. The coefficients of determination $\left(\mathrm{R}^{2}\right.$ model) were not increased by introducing protein balance (BADCP), the amount of PBV and AAT in the dry matter ingested, or the protein/energy ratio as alternative parameters of protein intake in the models. The levels of protein or energy intake did not significantly influence the levels of plasma albumin. The correlations between urea levels and other plasma indicators of metabolic status and liver function were generally low.
\end{abstract}

proteın metabolısm; energy intake; nutrition;

feed protein evaluation.

\section{Introduction}

Monitoring of feed adequacy is important for optimal feeding economy and good health and performance in dairy cows. The possibility of using the concentration of urea in milk as an indicator or aid in such moni- toring has recently attracted interest (Oltner et al. 1983, Refsdal et al. 1985).

The feeding of excessive amounts of easily degradable protein will increase the levels of ammonia in the rumen, and lead to an increase in the formation of urea in the liver. 
Accordingly, protein intake, and particularly the protein to energy ratio, has been shown to affect urea levels in blood and milk (Ide et al. 1966, Payne et al. 1970, Hewett 1974, Kaufmann 1982, Oltner \& Wiktorsson 1983, Refsdal et al. 1985).

The protein requirements of the ruminants and the protein value of their feeds are generally expressed as apparent digestible crude protein (DCP). The DCP system is easy to use, though it has several shortcommings. It does not differentiate between what has been absorbed as aminoacids and what has been absorbed as other nitrogenous constituents. Moreover it does not express the nitrogen requirements of the rumen microorganisms.

In order to correspondence the agreement between protein requirements and the estimated protein content of feed, and to optimalize the use of proteins in milk production, a new Nordic system for protein evaluation has been developed (Madsen 1985).

The advantage of the proposed system is that it predicts the amount of amino acids absorbed from the small intestine (AAT) and the nitrogen supply of the rumen microorganisms. This value is called the protein balance in the rumen (PBV). The system is easy to use, as the protein values for the single feeds can be added.

The present study was undertaken to establish the relationships between ammonia in rumen liquid, urea in milk and urea in plasma on the one hand, and the protein supply on the other, using traditional (DCP) and new (AAT, PBV) measures of feed protein value. Another objective was to investigate the relationships between urea levels and other plasma and feed constituents in early lactation.

\section{Materials and methods}

A feeding experiment was carried out with
28 Norwegian Red Cattle dairy cows. Taking date of calving into account, the cows were randomly distributed into 4 groups in which different feeding regimens were employed from 1 month prior to calving until 13 weeks after calving. There were 7 primiparous cows in all, which were, as far as possible, evenly distributed among the treatment groups.

Feeding treatments were factorial $(2 \times 2)$ with respect to protein content of the concentrate and concentrate allowances after calving. The levels of protein treatments were designated low (Lp) and high (Hp), feeding allowances (energy) being similarly low (Le) and high (He).

Concentrates were formulated to contain crude protein (CP) in dry matter (DM) at $175 \mathrm{~g} / \mathrm{kg}$ for LP and $240 \mathrm{~g} / \mathrm{kg}$ for $\mathrm{Hp}$. The 2 mixes were made up to provide similar amounts of rumen non-degradable protein (UDP) per $\mathrm{kg} \mathrm{DM}$, based on assumed degradability of CP (ARC 1980).

Before calving, the cows received $3 \mathrm{~kg}$ concentrates per day, and grass silage sufficient to achieve an energy intake of about twice the maintenance requirement (Breirem 1984). After calving, the amounts of concentrates fed were raised to predetermined levels, the He cows being allowed $3.5 \mathrm{~kg}$ /day more than Le cows at a given milk yield. Heifers in their first lactation received 1 $\mathrm{kg}$ /day more concentrates than older cows yielding the same amount of milk. Grass silage was fed ad libitum.

Energy values in fattening feed units (FFU) were estimated from in vitro digestibility of the silages, and from tabulated values for the ingredients in the concentrates (Breirem \& Homb 1971). Digestible crude protein (DCP) was calculated from the content of $\mathrm{N}$ (Thomsen \& Nøgaard 1983). Amino acids absorbable in the intestine (AAT) and protein balance in the rumen (PBV), were ob- 
tained according to principles described elsewhere (Madsen 1985). The degradability of feed protein was based on nylon bag measurements (Vik-Mo \& Lindberg 1985).

\section{Blood, milk and rumen liquid samples}

Blood samples were collected and treated as described by Ropstad et al. (1989). Plasma analyses were performed at the Department of Biochemistry, Norwegian College of Veterinary Medicine. Plasma acetoacetate (ACAC), glucose (GLUC), aspartate aminotransferase (ASAT), glutamate dehydrogenase, sorbitol dehydrogenase (SDH), free fatty acids and total bilirubin (BILI) assays were determined as described by Ropstad et al. (1989).

The levels of plasma albumin (reagents from General Diagnostics, USA) and plasma urea (PLUREA) (reagents from Roche Diagnostica, Switzerland) were estimated using commercial kits appropriate for the Gemsaec Analyzer (from Electro-Nucleonics Inc.).

Pooled morning and afternoon milk samples were collected twice weekly for the determination of urea levels (MUREA). The assay was carried out with a Technicon autoanalyzer using an appropriate commercial kit (Method no. SE 40001 FD4 from Technicon Instruments, USA).

Rumen liquid, withdrawn by a stomach tube, was collected every second week at 10 a.m. For preservation, $0.5 \mathrm{ml} 50 \%$ formic acid (vol/vol) was added to $10 \mathrm{ml}$ rumen liquid immediately after samplıng. The content of ammonia N (RNH3-N) was analyzed by a colorimetric reaction (Logsdon 1960) using a Technicon autoanalyzer.

\section{Statistical analysis}

Week averages calculated for all variables were subjected to analysis of variance. Sta- tistical analysis was performed by $S A S$ (1982) programmes (The GLM procedure). Levels of PLUREA, RNH3-N, MUREA and plasma albumin were evaluated by linear models which accounted for the effect of the individual animal factor (COW), the effect of week of lactation, the effect of protein intake, indicated either by total dietary PBV (TPBV) (Model B), total intake of AAT (TAAT) or by total intake of DCP (TDCP) (Model A), and the effect of energy intake (TFFU). Possible interactions were tested for significance and excluded from further analysis if not significant.

Alternatively, the dietary protein parameters were replaced by the protein/energy ratio (TPBV/TFFU and TDCP/TFFU), by the estimated balance of DCP, or by the estimated amount of protein (DCP or PBV) in the dry matter ingested (DMDCP and DMPBV). RNH3-N was used as an alternative protein parameter to explain the variation of urea in milk. Similarly, the animal factor (COW) was replaced by lactation number, body weight and milk yield or by protein treatment $(\mathrm{Hp}$ or $\mathrm{Lp})$. The variance contribution for each independent variable was calculated from its sum of squares type III (SS III) divided by total SS; i.e. (SS III/SS total) $x$ 100. Correlation analysis was used to assess the relationship between selected parameters. Testing for significance of the differences between coefficients of correlation was performed according to Snedecor (1959).

\section{Results}

Means and ranges for urea levels in milk and plasma, ammonia $\mathrm{N}$ in rumen liquid, and selected variables of nutrient intakes and metabolic status are shown in Table 1. Average body weight was $507 \pm 10( \pm \mathrm{SD})$ $\mathrm{kg}$. 


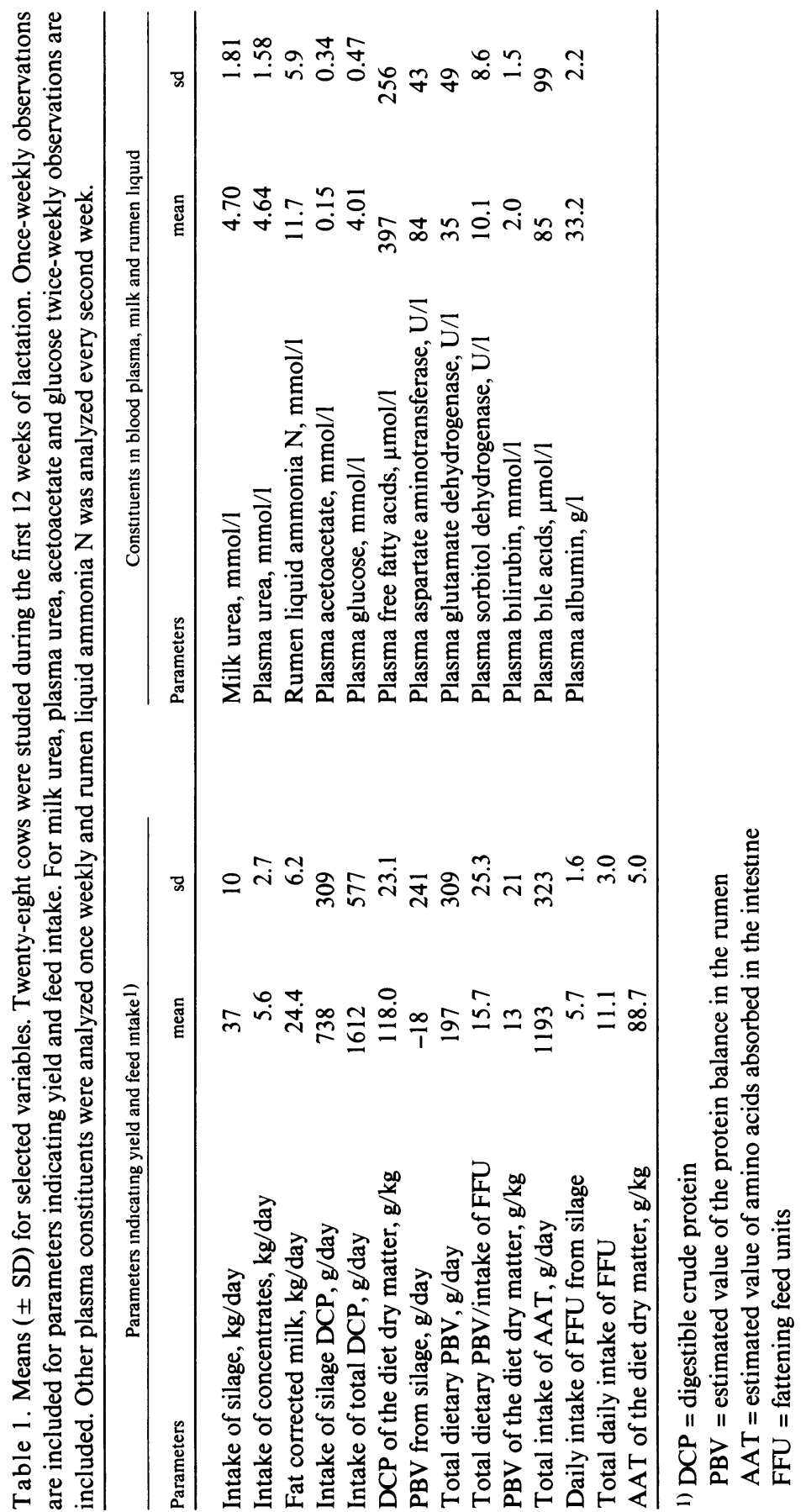


Significant relationships were found between protein intake (TPBV and TDCP) on the one hand, and PLUREA, MUREA and RNH3-N on the other (Table 2). Increased levels of protein intake were associated with increases in the level of urea in plasma and milk, and in the level of ammonia in rumen liquid. The partial regression coefficients for total dietary PBV (g/day) and total intake of DCP (g/day) on MUREA (mmol/l) were $0.0040(\mathrm{p}<0.001)$ and $0.0047(\mathrm{p}<0.001)$, respectively.

Replacing the measures of protein intake (TPBV and TDCP) with the protein to energy ratio (TPBV/TFFU and TDCP/TFFU), the estimated balance of DCP, and the estimated amount of PBV in the dry matter ingested (DMPBV) did not increase the coefficients of determination $\left(\mathrm{R}^{2}\right)$ for any of the models listed in Table 2.

Total intake of AAT as the protein parameter instead of total dietary PBV in Model A (Table 2) reduced the $\mathrm{R}^{2}$ for MUREA from $69.7 \%$ to $57.9 \%$. The variance contribution from TAAT was $8.3 \%$.

The highest $\mathbf{R}^{2}$ for MUREA (see Model A, Table 2) was found when rumen liquid am- monia- $\mathrm{N}$ was used as the protein parameter $\left(\mathrm{R}^{2}=76.7 \%, \mathrm{p}<0.001\right.$, variance contribution from RNH3-N $=25.3 \%, p<0.001$ ).

The effect of energy intake on MUREA and RNH3-N levels was negative, and significant only when total intake of DCP was used as the parameter of protein intake. The variance contributions from energy intake were low compared with those from protein intake (Table 2).

The use of total dietary PBV as a protein parameter instead of total intake of DCP did not improve the coefficient of determination for MUREA or RNH3-N (Table 2). However, the total correlation of MUREA with TPBV ( $r=0.74, p<0.001$, Fig. 1) was higher than with TDCP $(r=0.57, p<$ $0.001)$ or with TAAT $(r=0.30, p<0.001)$, the differences being significant with $\mathrm{p}<$ 0.001 .

According to Table 2, albumin was not significantly related to either protein or energy intake. No significant correlations were found between urea and albumin levels.

The variance contribution from the animal factor (COW) was $17.8 \%$ for plasma urea levels and $11.8 \%$ for milk urea levels (Mo-

Table 2. Analysis of variance. The levels of plasma urea (PLUREA), milk urea (MUREA), rumen liquid ammonia (RNH3-N) and albumin (ALB) were regarded as a function of the independent variables. Twenty-eight cows were studied durıng the first 3 months of lactation. Once-weekly observations are included except for RNH3-N which was measured every second week.

\begin{tabular}{|c|c|c|c|c|c|c|}
\hline \multirow{3}{*}{ Independent variables } & \multicolumn{6}{|c|}{ Percentage of total sum of squares 1 ) } \\
\hline & \multicolumn{3}{|c|}{ Model A } & \multicolumn{3}{|c|}{ Model B } \\
\hline & MUREA & PLUREA & RNH3-N & MUREA & RNH3-N & ALB \\
\hline Individual cow, $\mathrm{n}=28$ & $11.8^{\mathrm{c}}$ & $17.8^{\mathrm{c}}$ & $22.0^{\mathrm{a}}$ & $10.7^{c}$ & $22.4^{\mathrm{b}}$ & $27.4^{c}$ \\
\hline Week of lactation, $1-12$ & $1.8^{\mathrm{ns}}$ & $1.5^{\mathrm{ns}}$ & $2.6^{\mathrm{ns}}$ & $1.8^{\mathrm{ns}}$ & $2.6^{\mathrm{ns}}$ & $2.3^{b}$ \\
\hline Total dietary PBV & $20.0^{c}$ & $15.0^{\mathrm{c}}$ & $22.3^{c}$ & - & - & - \\
\hline Total intake of DCP & - & - & - & $20.4^{\mathrm{c}}$ & $22.8^{\mathrm{c}}$ & $0.3^{\text {ns }}$ \\
\hline Total intake of FFU & $0.4^{\mathrm{ns}}$ & $0.5^{\mathrm{ns}}$ & $0.5^{\mathrm{ns}}$ & $4.9^{c}$ & $4.6^{b}$ & $0.3^{\text {ns }}$ \\
\hline $\mathrm{R}^{2}$ model $(\%)$ & $69.7^{\mathrm{c}}$ & $71.4^{\mathrm{c}}$ & $60.1^{\mathrm{c}}$ & $70.2^{c}$ & $60.8^{c}$ & $31.9^{c}$ \\
\hline
\end{tabular}
1) Level of significance
a) $\mathrm{p}<0.05$,
b) $\mathrm{p}<0.01$
c) $\mathrm{p}<0.001$,
ns) $\mathrm{p}>0.05$. 


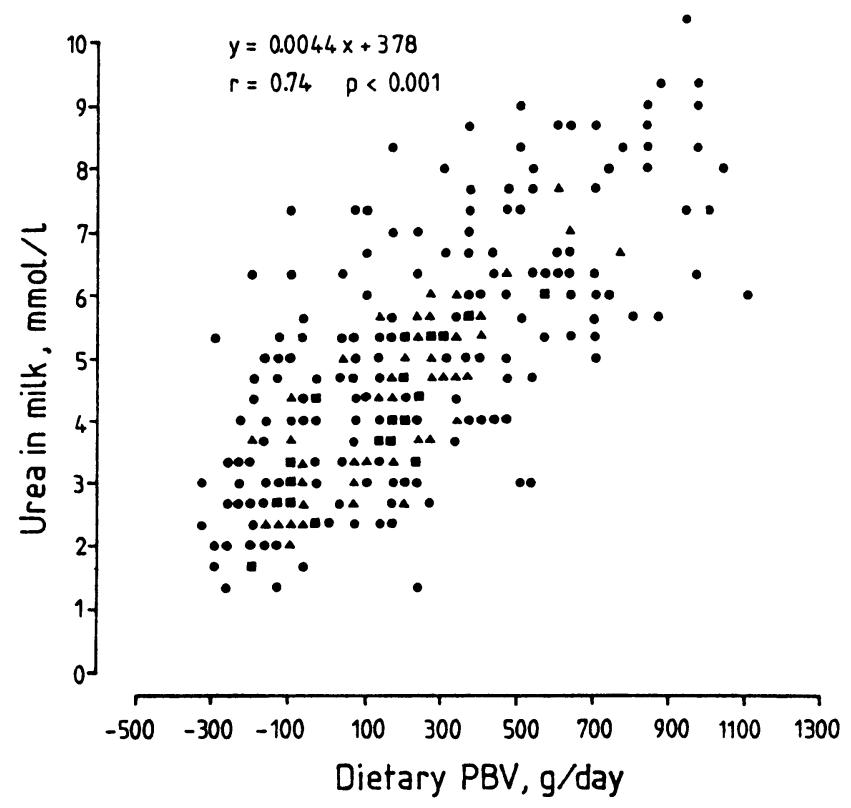

Figure 1. Relationship between total dietary PBV and the levels of urea in milk. Twenty-eıght cows were studied during the first 3 months of lactation. Once-weekly observations are included.

$\boldsymbol{\bullet}=1$ observation, $\boldsymbol{\Lambda}=\mathbf{2}$ observations, $\boldsymbol{\square}=\mathbf{3}$ or more observations.

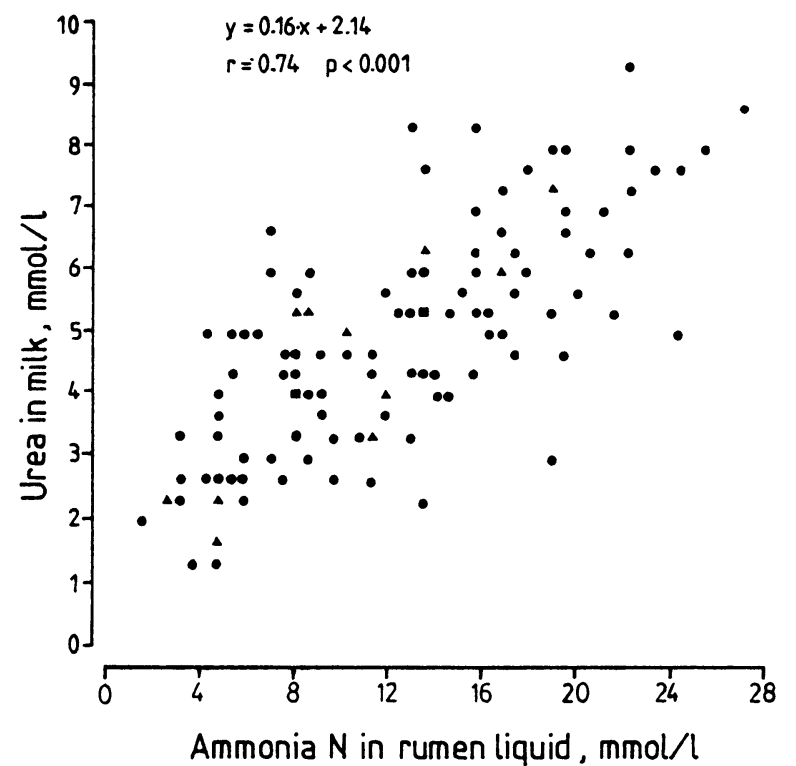

Figure 2. Relationship between the levels og ammonia in rumen liquid and urea in milk. Twenty-eight cows were studied during the first 12 weeks of lactation. Samples of rumen liquid were collected every second week.

$\bullet=1$ observation, $\Delta=2$ observations, $\boldsymbol{\square}=3$ or more observations. 
del $\mathrm{A}$, Table 2). In comparison, the variance contribution from total dietary PBV was $15.0 \%$ and $20.0 \%$ on the levels of plasma urea and milk urea, respectively.

In models alternative to those given in Table 2 , the individual factor (COW) was substituted by lactation number, body weight and milk yield, but none of these variables contributed significantly to the variation of plasma and milk urea, rumen liquid ammonia-N or plasma albumin levels ( $p>0.05$ ).

The substitution of the animal factor (COW) by protein treatment $(\mathrm{Hp}$ or $\mathrm{Lp}$ ) reduced the $\mathbf{R}^{2}$ for MUREA in Model B (Table 2) from $70.2 \%$ to $62.1 \%$. The effect of protein treatment was significant $(\mathrm{p}<0.001)$ with a variance contribution of $2.8 \%$. Excluding the animal factor in the same model gave a $\mathrm{R}^{2}$ for MUREA of $55.7 \%$.
The within animal coefficient of correlation between MUREA and PLUREA was $\mathrm{r}=$ $0.88(\mathrm{p}<0.001)$, and between MUREA and RNH3-N $r=0.75(p<0.001)$. The relationship between milk urea levels and rumen liquid ammonia- $\mathrm{N}$ levels is illustrated in Fig. 2. Both plasma urea and milk urea levels were significantly correlated with the levels of plasma free fatty acids $(r=-0.25, p$ $<0.01$ and $\mathrm{r}=-0.28, \mathrm{p}<0.001$, respectively) and plasma glutamate dehydrogenase $(r=$ $0.17, \mathrm{p}<0.05$ and $\mathrm{r}=0.18, \mathrm{p}<0.05$, respectively). The other plasma constituents (ACAC, GLUC, ASAT, SDH, BA, BILI) were not significantly correlated with urea levels in milk or ammonia levels in rumen liquid.

Highly significant correlations were found between several of the energy and protein intake parameters (Table 3 ).

Table 3. Correlation coefficients between measures of energy and protein intake. The correlations are based on weekly estımates from 28 dairy cows during the first 12 weeks of lactation, represented by weekly analysis.

\begin{tabular}{llllllllll}
\hline & \multicolumn{8}{c}{ Coefficients of correlation1) } \\
\cline { 2 - 10 } Variables2) & TPBV & SPBV & TAAT & SDCP & TDCP & TPBV/TFFU & TFFU & DMPBV & DMDCP \\
\hline TPBV & 1.00 & & & & & & & & \\
SPBV & $0.79^{\mathrm{c}}$ & 1.00 & & & & & & & \\
TAAT & $0.37^{\mathrm{c}}$ & $-0.01^{\mathrm{ns}}$ & 1.00 & & & & & & \\
SDCP & $0.59^{\mathrm{c}}$ & $0.66^{\mathrm{c}}$ & $0.31^{\mathrm{c}}$ & 1.00 & & & & & \\
TDCP & $0.76^{\mathrm{c}}$ & $0.38^{\mathrm{c}}$ & $0.87^{\mathrm{c}}$ & $0.51^{\mathrm{c}}$ & 1.00 & & & & \\
TPBV/TFFU & $0.97^{\mathrm{c}}$ & $0.82^{\mathrm{c}}$ & $0.24^{\mathrm{c}}$ & $0.57^{\mathrm{c}}$ & $0.65^{\mathrm{c}}$ & 1.00 & & & \\
TFFU & $0.40^{\mathrm{c}}$ & $0.05^{\mathrm{ns}}$ & $0.99^{\mathrm{c}}$ & $0.33^{\mathrm{c}}$ & $0.89^{\mathrm{c}}$ & $0.08^{\mathrm{ns}}$ & 1.00 & & \\
DMPBV & $0.96^{\mathrm{c}}$ & $0.81^{\mathrm{c}}$ & $0.29^{\mathrm{c}}$ & $0.67^{\mathrm{c}}$ & $0.58^{\mathrm{c}}$ & $0.99^{\mathrm{c}}$ & $0.30^{\mathrm{c}}$ & 1.00 & \\
DMDCP & $0.93^{\mathrm{c}}$ & $0.71^{\mathrm{c}}$ & $0.38^{\mathrm{c}}$ & $0.46^{\mathrm{c}}$ & $0.72^{\mathrm{c}}$ & $0.97^{\mathrm{c}}$ & $0.39^{\mathrm{c}}$ & $0.97^{\mathrm{c}}$ & 1.00 \\
\hline
\end{tabular}

1) Level of significance: c) $p<0.001, \mathrm{~ns}) \mathrm{p}>0.05$

2) TPBV: Total dietary PBV

SPBV: $\quad$ Silage PBV

TAAT: Intake of total AAT

SDCP: Intake of DCP from silage

TDCP: Intake of total DCP

TFFU: Intake of total FFU

DMPBV: PBV in the diet dry matter

DMDCP: DCP in the diet dry matter 


\section{Discussion}

The mean urea levels in milk were in accordance with the levels found in bulk milk under field conditions (Refsdal et al. 1985), though slightly lower than those reported by Ropstad \& Refsdal (1987) and Härstad (1985).

The present results support earlier findings that the levels of urea in milk and plasma and the level of ammonia in rumen liquid, are dependent on protein intake (Lewls 1957, Ide et al. 1966, Payne et al. 1970, Hewett 1974). Both total dietary PBV and total intake of DCP contributed significantly to the variation in MUREA and RNH3-N (Table 2). The higher total correlation of MUREA with TPBV $(\mathrm{r}=0.74, \mathrm{p}<0.001)$ than with TDCP $(r=0.57, p<0.001)$ may be due to the influence of dietary energy, included in the calculation of TPBV. Total intake of AAT showed a lower total correlation with MUREA than did either total intake of DCP or total dietary PBV, and the analysis of variance revealed that the variance contribution from this factor on the MUREA variation was less than the contributions from TDCP and TPBV. Total intake of AAT is an expression of metabolizable aminoacids in the body. A large proportion of the available aminoacids is used for milk synthesis, and this may explain the lower variance contribution on urea levels from TAAT than from total intake of DCP and total dietary PBV.

Results of the present study indicate that the levels of urea measured in milk and plasma are markedly influenced by the extent of ammonia losses from protein by degradation processes in the rumen. Attention is drawn to the very high coefficient of determination for MUREA $\left(R^{2}=76.7 \%\right)$ found when rumen liquid ammonia- $\mathrm{N}$ was used as the protein parameter in the models listed in Table 2. In a previous experiment (Oltner \& Wik- torsson 1983), milk urea concentrations were found to be closely correlated to the protein/energy ratio in the feed ration, whereas the total amount of feed consumed had little influence. In the present study, the estimated TPBV values closely reflected both the protein/energy ratio and the content of protein in dry matter (Table 3 ). This is in line with the principles of PBV estimation (Madsen 1985) and feed composition. It remains to be seen in further feeding experiments if total dietary PBV (TPBV) can be used as a general indicator of the urea content in cow's milk.

Levels of urea in milk are subject to considerable individual variation in groups of animals offered the same amount of identical feeds. This has therefore to be taken into consideration when evaluating the suitab1lity of milk urea as an aid in monitoring feeding regimens. The individual factor indeed proved to be a prominent source of variation in the present study (Table 2). According to Oltner et al (1983), indivudual variation is partly due to body weight and the age of the cow. In the present study, body weight, lactation number and milk yield did not contribute significantly to the variation of urea levels in milk or plasma. However, the results provide evidence that the effect of protein treatment ( $\mathrm{Hp}$ and $\mathrm{Lp}$ ) may have contributed to the large variance contributions from the animal factor (see Table 2 and Results).

Due to the random variation between cows, it is probably not possible to estimate the nutritional status of a cow directly from its milk urea concentration, though more reliable information can be obtained if measurements are repeated over time. When milk urea determinations are performed on groups or herds, direct inferences regarding the adequacy of feeding is possible. Attention is drawn to the results obtained by 
Refsdal et al (1985), who found a significant correlation $(r=0.64, p<0.001)$ between bulk milk urea levels and average percentage of crude protein in the silage dry matter.

The correlations between milk and plasma urea levels and other plasma constituents were generally low. The biological significance of the correlations found between levels and both FFA and GLDH is difficult to interpret. Probably they are confounded by other sources of variation and do not express the true relationship between the parameters concerned. The lack of relation between plasma albumin and the protein supply contrasts with the findings of others (Hewett 1974, Payne \& Payne 1987). However, the protein/energy ratio in the diet was relatively high in all cases in the present study, and this may have limited any potential response of albumin to protein level per se. Frequent sampling of the limited number of animals included in this study, combined with the long half life of albumin, may also have contributed to our findings.

Optimal utilization of forage protein is dependent on a balance between the supply of degradable protein and the production of microbial protein. According to the regression in Fig. 1, a milk urea level of about 3.8 $\mathrm{mmol} / \mathrm{l}$ plasma or milk would reflect a condition where the supply of dietary protein equals the amount synthesized by the rumen microorganisms. The mean urea levels found among Norwegian cows are considerably higher (Hårstad 1985, Refsdal et al 1985, Ropstad \& Refsdal 1987), a situation which may reflect an excessive protein supply in feed rations to Norwegian cows. However, further investigations are necessary to establish firm figures for optimal urea levels of blood and milk in dairy cows.

\section{References}

Agricultural Research Council (ARC) The Nutr1ent Requirement of Livestock. Commonwealth Agricultural Bureaux, Slough 1980.

Breırem $K$ Fôrnormer. (Feed standards). In $\mathrm{K}$. Sıngsaas: K. K. Heje Lommehåndbok. P. F. Stensballes Forlag, Oslo 1984, pp. 188-200.

Breırem K, Homb $T$ Fôrmidler og fôrkonservering. (Feeds and feed preservation). Forlag $\mathrm{Bu}-$ skap og Avdrått A/S, Gjøvık 1971.

Hewett $C$ On the causes and effects of variations in the blood profile of Swedish dairy cattle. Acta vet. scand. 1974, Suppl. 50.

Hårstad $E$ Sammenhengen mellom fôring, ureainnhold 1 mjølk og fruktbarhet hjå mjølkekyr. (The relationshıp between nutrition, urea content in milk and fertility in dairy cows). Thesis. The Department of Anımal Nutritıon, The Agricultural Unıversity of Norway, 1985, $112 \mathrm{pp}$.

Ide $Y$, Shımbayash $K$, Yonemura $T$ Effect of dietary conditions upon serum- and milkurea nitrogen in cows. I. Serum- and milkurea nitrogen as affected by protein intake. Jap. J. vet. Sc1. 1966, 28, 321-327.

Kaufmann $W$ Vanation in der Zusammensetzung des Rohstoffes Milch unter besonderer Berücksichtıgung des Harnstoffgehaltes. (Vanation in the urea content of milk used for processing). Milchwiss. 1982, 37, 6-9.

Lewis $D$ Blood-urea concentration in relation to protein utilization in the ruminant. J. agric. Sc1. 1957, 48, 438-446.

Logsdon EE A method for determination of ammonia in biological materials on the AutoAnalyzer. Ann. New York acad. Sc1. 1960, 87, 801-807.

Madsen $J$ The basis for the proposed Nordic protein evaluation system for ruminants. The AAT-PBV system. Acta agric. scand. 1985, suppl. 25, 9-20.

Oltner $R$, Emanuelson $M$, Wiktorsson $H$ Urea concentration in cow's milk in relation to milk yield, live weight, lactation number and amount and composition of feed given. In: $\mathbf{R}$. Oltner: Factors affecting certain blood constituents and milk urea in Swedish dairy cattle. Thesis. Swedish University of Agricultural Sciences, Uppsala 1983. 
Oltner $R$, Wiktorsson $H$. Urea concentrations in milk and blood as influenced by feeding varying amounts of protein and energy to dary cows. Livest. Prod. Sci. 1983, 10, 457-467.

Payne JM, Dew SM, Manston R, Faulks $M$ The use of the metabolic profile test in dairy herds. Vet. Rec. 1970, 87, 150-157.

Payne JM, Payne $S$ Indicators of protein status. In: The Metabolic Profile Test. Oxford University Press 1987, pp. 27-35.

Refsdal AO, Bavre L, Bruflot $R$ Urea concentration in bulk milk as an indicator of the protein supply at the herd level. Acta vet. scand. 1985, 26, 153-163.

Ropstad E, Halse K, Refsdal AO Variations in parameters of liver function and plasma progesterone related to underfeeding and ketosis in a dairy herd. Acta vet. scand. 1989, 30, 185-197.

Ropstad E, Refsdal AO Herd reproductive performance related to urea concentration in bulk milk. Acta vet. scand. 1987, 28, 55-63.

SAS (Stattstical Analysis System) SAS User's Guide: Statıstıcs. SAS Instıtute Inc., Cary, N.C. 1982.

Snedecor $\mathrm{SW} \cdot$ Statistical Methods. Iowa State College Press, 1959, 534 pp.

Thomsen $K V$, Nøgaard $P$ - Fodermidlernes karakteristika. (Characteristics of feed stuffs). Beretninger fra Statens Husdyrbrugsforsøk, No. 551, Copenhagen 1983, $37 \mathrm{pp}$.

$V l k$-Mo L, Lindberg $J E$ In sacco degradability of protein $(\mathrm{N})$ and dry matter in samples of individual feed or combinations, tested with diets medium or high in protein. Acta agric. scand. $1985,35,117-128$.

\begin{abstract}
Sammendrag
Nıvåer av urea $\mathrm{l}$ melk, plasmabestanddeler og ammoniakk $\mathrm{l}$ vomsaft $\iota$ relasjon til fôrıng av melkeku i tidlig laktasjon.
\end{abstract}

Undersøkelsen ble gjennomført for å undersøke ureanivå i melk og plasma i relasjon til proteınınnhold 1 fôret uttrykt ved tradısjonelle og nye proteinvurderingsmål.

Prøver av melk og plasma ble tatt før morgenfôring to ganger 1 uken de tre første laktasjonsmåneder fra 21 multıpare kyr og 7 kviger. Vomsaftprøver ble tatt hver 2. uke. Kyrne ble fordelt på 4 fôringsgrupper 1 et faktorielt opplegg med hensyn til proteininnhold 1 kraftfôr (dvs. Hp: 17,5 \% fordøyelıg råprotein (DCP) mot Lp: 12,5 \% DCP) og kraftfôrnıvå (dvs. Le: underfôring mot He: normfôring). Surfôr ble gitt etter appetitt.

Innen dyr korrelasjoner mellom urea 1 melk og plasma var $r=0.88(p<0.001)$ og $r=0.75(p<$ 0.001 ) mellom urea i melk og ammoniakk i vomsaft. Ved variansanalyse ga følgende faktorer et signifikant bıdrag tıl variasjonen i urea i melk og plasma: Proteinbalansen 1 vomma (PBV), inntak av aminosyrer absorbert i tarmen (AAT), intak av DCP, inntak af forrenheter og individ. Det samme mønster ble funnet for varıasjonen av ammoniakk 1 vomsaft. Variansbidraget fra modellene ble ikke økt ved å bruke proteinbalanse (BADCP), mengden af PBV og AAT 1 opptatt tørrstof eller forholdet mellom energi og proteın som alternative parametre for proteininntak i modellene. Nivåene av energi- og proteınınntak bidro ikke til å forklare variasjonen 1 plasma albumin. Korrelasjonene mellom urea og andre indikatorer på metabolsk status og leverfunksjon var generelt lave.

(Recelved March 23, 1988; accepted August 18, 1988).

Reprints may be requested from: Erık Ropstad, Norwegian College of Veterınary Medicıne, P. O. Box 8146 Dep., N-0033 Oslo 1, Norway. 